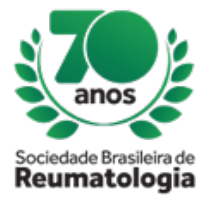

\title{
INCOMPLETE ANTISYNTHETASE SYNDROME IN WOMEN
}

Elisa Fernandes de Melo (Universidade de Taubaté, Taubaté, SP, Brasil), Vinicius Verlangieri Soubihe (Universidade de Taubaté, Taubaté, SP, Brasil), Raylane Shellyda de Almeida Anate (Universidade de Taubaté, Taubaté, SP, Brasil), Natália Engler Ravasio (Universidade de Taubaté, Taubaté, SP, Brasil), José Roberto Megda Filho (Universidade de Taubaté, Taubaté, SP, Brasil), Laís Helena Bittencourt Ribeiro Soubhia (Universidade de Taubaté, Taubaté, SP, Brasil)

\section{BACKGROUND}

Antisynthetase syndrome (ASS) is an autoimmune disease characterized by Raynaud's phenomenon, fever, interstitial lung disease, myopathy, polyarthritis and "mechanics hands". Diagnostic criteria require one or more of the clinical features and one or more antisynthetase antibodies (which target tRNA synthetase enzymes), especially anti-Jo-1. It is a rare disease with an unknown incidence in the general population but is twice more prevalent in women than in men. Interstitial Lung Disease (ILD) is the main determinant of morbidity and mortality in ASS.

\section{CASE REPORT}

A 51 years old woman presenting fever and dyspnea with moderate exertion for 45 days. Hospitalized to treat a pulmonary infection with antibiotic and diagnostic investigation. During the physical examination the presence of mechanics hands (figure 1) was noticed and the laboratory exams showed leukocytosis with left-shift up to metamyelocytes, ESR 100, reagent ANA 1:160 dense thin speckled cytoplasmic, positive aldolase $(18,5)$ and negative anti-Jo-1. Chest CT demonstrated multiple irregular opacities with dense lattices and ground-glass opacification diffusely in both lungs and bilateral pleural thickening (figure 2). Cultures for common bacteria, atypical, mycobacteria and exams for fungal infections were negatives. Considering clinical condition, imaging and laboratory exams, criteria were established for ASS. Initiated methylprednisolone pulse therapy followed by oral corticosteroid and monthly cyclophosphamide, with remission of the pulmonary condition.

\section{CONCLUSION}

ASS is a rare disease, with ILD being the main determinant of morbidity and mortality. Besides the ANA with dense fine speckled cytoplasmic pattern, we have the anti-synthetase antibodies and the anti-Jo-1 being positive in $70 \%$ of the cases. It is expected that a greater awareness of the clinical features of this syndrome will allow earlier diagnosis and appropriate treatment to improve results of these patients. 